\title{
Metabolic and digestive enzyme activity profiles of newly hatched spotted wolffish (Anarhichas minor Olafsen): effect of temperature
}

\author{
Arianne Savoie ${ }^{1,2}$, Nathalie R Le François ${ }^{1,2,{ }^{*}}$, Chantal Cahu ${ }^{3}$, Pierre U Blier ${ }^{1}$ \\ ${ }^{1}$ Laboratoire de biologie animale intégrative, Université du Québec à Rimouski, QC, Canada \\ ${ }^{2}$ Ministère de l'Agriculture, des Pêcheries et de l'Alimentation du Québec, Centre aquacole marin, Grande- \\ Rivière, QC, Canada \\ ${ }^{3}$ Unité Mixte INRA IFREMER de Nutrition des Poissons, Plouzané, France \\ *: Corresponding author : Nathalie R Le François, email address : Nathalie Le-Francois@uqar.qc.ca, Tel : 418- \\ 385-2251 (222), Fax : 418-385-3343
}

\begin{abstract}
:
Three groups of newly hatched spotted wolffish (Anarhichas minor) were held at three different temperatures in order to determine relationships between metabolic, digestive and growth response in rapidly developing larvae. Growth rates were successfully modulated by temperature $\left(5,8\right.$ and $\left.12{ }^{\circ} \mathrm{C}\right)$. Activity levels of trypsin and lactate dehydrogenase (LDH) were positively linked to specific growth rates at all temperatures. Trypsin showed a positive compensation (higher activity at lower temperature) whereas glycolytic enzymes (pyruvate kinase and Lactate dehydrogenase) and aspartate aminotransferase (AST) showed a negative compensation (lower activity at lower temperature). Citrate synthase was not affected by growth rate, indicating that the level of aerobic capacity was adequate in sustaining the high energetic needs associated with rapid growth early in the life of the spotted wolffish. In light of our results, it is suggested that protein digestion, as demonstrated by the activity profile of trypsin in relation to growth rate and temperature, is likely a key growth-limiting agent during the early-life stages of wolffishes. Our results are discussed in comparison with A. lupus, a closely related species displaying different temperature preferences and growth capacities.
\end{abstract}

Keywords: digestive capacities, energy metabolism, growth, temperature, Anarhichas minor 


\section{Introduction}

Newly-hatched fish are at their most vulnerable during this stage of development. Paradoxically, it is also at this critical period that they will experience extremely dynamic and complex processes of organogenesis and morphogenesis, and experience the highest growth rate that they will ever achieve in their entire lifetime (Sala, Santamaria \& Crespo, 2005). Critical aspects governing larval success lies in their capacity to grow and be successful at locating, catching, digesting and assimilating prey. These processes will in turn translate into the availability of nutritional energy to sustain basic physiological requirements while avoiding predation (Jobling 1995; Gawlicka, Parent, Horn, Ross, Opstad \& Torrissen, 2000). Accordingly, failure to meet nutritional needs through ingestion, digestion or assimilation will result in impaired growth, starvation, reduced viability and ultimately death (Bureau, Kaushik \& Young Cho, 2002).

Energy-rich molecules processed by the digestive system are made available to the different metabolic pathways in order to produce sufficient ATP to sustain the high protein turnover rate associated with high growth rate (Houlihan, McCarthy, Carter \& Martin, 1995). Metabolic and digestive capacities are two physiological processes proposed to be involved in restraining fish growth (Houlihan, Hall, Gray \& Noble, 1988; Lemieux, Le François \& Blier, 2003). Several studies report strong relationships between glycolytic (Lamarre, Le François, Falk-Petersen \& Blier, 2004;; Lamarre, Le François, Lemieux, Falk-Petersen \& Blier, in press), mitochondrial (Pelletier, Guderley \& Dutil, 1993b; Blier, Dutil, Lemieux, Bélanger \& Bitetera 2007), and digestive (Lemieux, Blier \& Dutil, 1999) enzyme activities and growth. Indicators of proteolysis and amino acid utilization (trypsin and aspartate aminotransferase (AST), respectively) in the alimentary tract are correlated with plasmatic free amino acid (AA), which may in turn modulate rate of protein synthesis, and ultimately growth and survival in fish (Carter, Ye, Houlihan, McCarthy \& Davison, 1995; Hardewig \& Van Dijk, 2003; Pérez-Jiménez, Guedes, Morales \& Oliva-Teles, in press)

Temperature is one of the most important environmental factors influencing the physiological processes in fish. Growth commonly shows strong temperature dependence, while most functions such as swimming activity, oxygen consumption, digestion and enzyme activity can exhibit varying degrees of temperature compensation capacities in order to minimize seasonal effects (Johnston \& Dunn, 1987) or allow access to a wider variety of habitats (Somero, 1969).

The spotted wolffish (Anarhichas minor Olafsen) is a marine fish species very well suited for cultivation under cold northern climates (Le François, Lemieux \& Blier, 2002; Foss, Imsland, FalkPetersen \& Oiestad, 2004). The range of temperature tolerated by spotted wolffish lies within subzero temperatures (Desjardin, Le François, Fletcher \& Blier, 2006) to over ${ }^{\circ} 4^{\circ} \mathrm{C}$ (Hansen \& Petersen, 2002). The most striking advantages of raising this species resides in: 1) the low complexity of the larval-juvenile period, 2) its high growth rate at low water temperature, and 3) its farming-friendly behaviour. Furthermore, the Committee on the Status of Endangered Wildlife (COSEWIC: www.cosewic.gc.ca ) has identified the spotted wolffish as a threatened species in Canadian coastal waters. At hatching, wolffishes are very large in size $(20-24 \mathrm{~mm})$ and welldeveloped compared to most marine fish species of aquaculture interest. This family of fish displays a fully functional digestive system at hatch and will readily accept formulated feed from day one (Falk-Petersen \& Hansen, 2001; Lamarre et al., 2004). However, based on captive broodstock (wild and/or domestic origin), wolffish juvenile production still presents a fair degree of variability in terms of survival during first-feeding operations (Falk-Petersen \& Hansen, 2003; Lamarre et al. 2004, Savoie, Le François, Falk-Petersen, Blier \& Andreassen, 2006). Falk-Petersen, Hansen, Fieler \& Sunde (1999) and Lamarre et al. (2004; in press) suggested that variable survival during start-feeding operations might be linked to abnormalities of the mucosa cells of the digestive tract or to inadequate levels of digestive and assimilation capacities at hatch. A better understanding of the impact of temperature during early-growth in relation with energy metabolism and digestive capacities is, therefore, of primary importance in identifying the conditions that govern successful weaning to an exogenous food source and maximal expression of early-growth capacities. 
The interaction between metabolic activity and digestion is particularly crucial since both components greatly influence growth rate. The aim of our study was to investigate the extent to which growth rate is related to metabolic and digestive enzyme activities in $A$. minor reared at different temperatures. Metabolic capacities were evaluated through the measurement of citrate synthase (CS: aerobic capacity), lactate dehydrogenase (LDH: anaerobic glycolysis) and pyruvate kinase (PK: aerobic glycolysis). Aspartate aminotransferase (AST: an indicator of amino acid catabolism) was assessed in parallel with trypsin activity (protein digestion). Trypsin is the only digestive enzyme that has displayed a positive correlation with growth rate in previous studies on fish (Atlantic cod, Gadus morhua L.: Lemieux et al., 1999; and the roach, Rutilus rutilus L: Hardewig \& Van Dijk, 2003). Lamarre et al. (2004) working on Atlantic wolffish (Anarhichas lupus L.), a closely related species, linked trypsin activity level on hatching day to subsequent survival and weight but failed to clearly relate its activity to growth rate. We sought to study the spotted wolffish and to employ temperature to generate a range of growth and enzyme activity rates. We believe that, in comparison to the Atlantic wolffish, the reported lower levels of stress and dominance behaviour in captivity (Foss et al., 2004) displayed by $A$. minor should reduce the expenditures related to spontaneous swimming activity levels and intra-specific growth variability associated and allow a clearer evaluation of the links among temperature, growth rate and digestive and metabolic capacities.

\section{Material and methods}

\subsection{Experimental fish and rearing conditions}

The study was carried out at the facilities of the Centre Aquacole Marin de Grande-Rivière, Québec, Canada. Spotted wolffish eggs from three different females were provided by Troms Steinbit (Tromsø, Norway). The eggs were approximately 550 degree-days at their arrival in Québec, Canada. Egg masses were incubated separately in serial upwelling incubators at $5{ }^{\circ} \mathrm{C}$. Periodic disinfections were performed as prescribed by Hansen \& Falk-Petersen (2001). Hatching began on November $9^{\text {th }}, 2004$ and in order to obtain a high number of larvae simultaneously to initiate the growth trials, hatching was provoked by gentle pressure on the eggs. Forty newly hatched spotted wolffish (mean weight $0.103 \pm 0.01 \mathrm{~g}$ and mean length $24.5 \pm 1.4 \mathrm{~mm}$ ) from the three families were randomly placed in 36 low-level $(2 \mathrm{~cm})$ rearing units containing 1.5 litres, with a water supply of 0.5

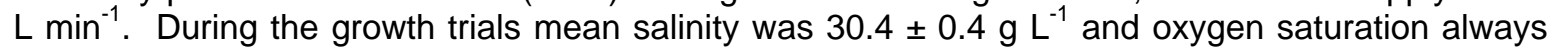
above $80 \%$ (mean $97.0 \pm 5.5 \%$ ). Luminosity was between $800-1000$ lux and a 12/12-h light/dark cycle was adopted. Fish were reared at three temperatures $\left(5.2 \pm 0.8,8.0 \pm 0.3\right.$, and $11.5 \pm 0.8{ }^{\circ} \mathrm{C}$, 12 tanks per temperature). The fish transferred at temperature above $8^{\circ} \mathrm{C}$, were gradually acclimated to their respective temperature (1 degree per hour). Mortality assessment, dead fish removal and careful cleaning of the rearing units were performed daily.

Fish were fed Artemia nauplii in combination with a formulated fish feed (formulated and processed at Ifremer, Centre de Brest, France) for the first two weeks post-hatch. During this period, the feed was offered every hour from 08:00 to 17:00. The fish were weaned onto only the formulated feed after 2 weeks and hand-fed in excess. The formulated feed was processed as follows: ingredients were mechanically mixed with water, pelletized and dried at $50{ }^{\circ} \mathrm{C}$ for 20 min (Cahu, ZamboninoInfante, Quazuguel \& Gall, 1999). The pellets were sieved to obtain different particle sizes of 200$400,400-600,600-800,800-1000$ and 1000-1200 $\mu \mathrm{m}$. Two sizes of particles were given in combination if a group was heterogenous. 


\subsection{Sampling}

Fish were sampled over 60 days at different intervals: hatching day $(n=14), 15$ days post-hatch (DPH) ( $n=36$ per temperature), $30 \mathrm{DPH}$ ( $n=36$ per temperature), and $60 \mathrm{DPH}$ ( $n=36$ per temperature). Fish were fasted for 18 hours before sampling. Individual weight and length were measured and whole fish were quickly frozen at $-80^{\circ} \mathrm{C}$ until enzymatic analysis was performed. Specific growth rate (SGR) was calculated as follows:

SGR $\left(\%\right.$ day $\left.^{-1}\right)=\left(\ln W_{t 2}\right)-\left(\ln W_{t 1}\right) \cdot(\text { experimental time in days })^{-1} \times 100$.

Where $W_{t 1}$ is mean weight $(g)$ of the fish at hatching, $W_{t 2}$ is mean final weight of the fish.

\subsection{Enzymatic assays}

Whole individuals were thawed on ice and homogenized in 9 volumes of Tris- $\mathrm{HCl}$ buffer $(100 \mathrm{mM}$, $\mathrm{pH}$ 7.5) using an Ultra Turrax T25 (IKA Labortechnik) electrical homogeniser for three $10 \mathrm{~s}$ periods. Between each period, samples were kept on ice for $1 \mathrm{~min}$. An aliquot of the homogenate was centrifuged (400 $\mathrm{g}$ for 1 minute) for aspartate aminotransferase (AST, EC 2.6.1.1), citrate synthase (CS, EC 2.3.3.1), pyruvate kinase (PK, EC 2.7.1.40), and lactate dehydrogenase (LDH, EC 1.1.1.27 ) assays. Another aliquot was centrifuged (13 $000 \mathrm{~g}$ for 15 minutes) for trypsin assays. Enzyme activities were measured using a Lambda 40 UV/VIS spectrophotometer equipped with a thermostated cell holder (Perkin Elmer Inc.); assay conditions are presented in Table 1.

Activities of AST, CS, PK and LDH were measured according to the methods described by Lemieux et al. (2003) and TRYP was measured according to Preiser, Schmitz \& Maestracci (1975) with modifications. Total protein content was determined using the bicinchoninic acid method (Smith, Krohn, Hermanson, Mallia, Gartner, Provenzano, Fujimoto, Goeke, Olson \& Klenk, 1985). Assays were conducted at $15{ }^{\circ} \mathrm{C}$ and protein analyses were carried out at room temperature. All assays were run in duplicate. Enzymatic activities were expressed as $\mathrm{U} \mathrm{mg}^{-1}$ protein to ensure that an increase in any particular enzyme did not reflect a general increase in protein content.

\section{Statistical analysis}

Mean SGRs were compared among temperatures by analysis of variance using the general linear model procedure in the Systat 10.2 computer software (SPSS inc., 2002). When a significant difference was detected, a Tuckey post-hoc test was used (Zar, 1984). To detect a potential effect of temperature and their potential interactive effect on growth rate and enzymatic activities, analysis of variance (temperature, SGR and temperature X SGR) was performed using the general linear model procedure. When a significant interaction was detected between temperature and growth rate, a linear regression of growth rate vs. enzymatic activity was performed for each temperature and slopes were compared and considered significantly different when the $95 \%$ confidence interval of the slope did not overlap between two treatments. Treatments were considered significantly different when $\mathrm{P}<0.05$. 


\section{Results}

As reported in a parallel study using the same experimental fish (Savoie et al., 2006), survival from hatching to $60 \mathrm{DPH}$ was significantly higher for groups at temperatures below $12{ }^{\circ} \mathrm{C}(50,54$, and $33 \%$ at 5,8 , and $12{ }^{\circ} \mathrm{C}$, respectively). Mortalities stabilized at day 53, 42 and 28 for groups at 5, 8, and $12{ }^{\circ} \mathrm{C}$. Growth was successfully modulated by temperature $(2.01 \pm 0.51,4.06 \pm 0.57$ and 4.77 $\pm 0.55 \% \cdot$ day $^{-1}$, from $0-60 \mathrm{DPH}$, at 5,8 and $12^{\circ} \mathrm{C}$, respectively).

Protein content decreased at $15 \mathrm{DPH}$ compared to day 0 but returned to comparable value at 30 $\mathrm{DPH}$. Protein content was significantly different among the different temperature treatments from $30 \mathrm{DPH}$ (results not shown). A linear regression was made of protein content as function of SGR; there was a significant effect of temperature $(P=0.034)$ and SGR $(P<0.001)$, and a significant interaction between those two factors $(P=0.003)$. The correlation coefficient $\left(R^{2}\right)$ was 0.59 . The linear regressions showed that the slope at $5{ }^{\circ} \mathrm{C}$ was significantly steeper than that at $12{ }^{\circ} \mathrm{C}$.

There were significant differences in AST activity among experimental temperatures from day 30 (Figure 1a). Citrate synthase activity was not significantly different between temperature (mean activity level of $0.06 \pm 0.02 \mathrm{U} \mathrm{mg}$ protein ${ }^{-1}$ ). No relationships among AST or CS activity and SGR were detected, nor any interaction between temperature and SGR (results not shown).

Significant differences of TRYP activity levels among temperatures were observed at 15 and 60 $\mathrm{DPH}$ (Figure 1b). At $60 \mathrm{DPH}$, activity was lower at higher temperature (highest with decreasing temperature). TRYP activity was positively related to SGR at all temperature $\left(R^{2}=0.522\right)$ and there was a significant interaction between SGR and temperature $(p<0.001$, Figure $2 a)$. The slope was significantly steeper at $5^{\circ} \mathrm{C}$ compared to the two other temperatures ( 3 times lower at $12{ }^{\circ} \mathrm{C}$ compared to $\left.5^{\circ} \mathrm{C}\right)$.

Pyruvate kinase and LDH activities were significantly different among the temperature treatments after $30 \mathrm{DPH}$ (Figure 1c and d). Activity of both glycolytic enzymes were positively related to temperature (higher with increasing temperature). Activity of LDH was positively related to SGR $\left(R^{2}=0.502, p=0.006\right.$, Figure $\left.2 b\right)$ and there was an effect of temperature $(p=0.002)$, but no interaction between the two factors was detected $(p=0.226)$ as illustrated by the parallel slopes. The linear regression of SGR and PK activity was not significant (results not shown).

\section{Discussion}

Despite the fact that growth is an energetically costly process, aerobic capacity, as indicated by CS activity level, did not adjust to the higher rate of protein deposition associated with higher growth rate. This is indicative that newly hatched spotted wolffish rely on adequate metabolic capacities to sustain their growth during early life (up to $10 \%$ body weight. day ${ }^{-1}$ for some individuals). It has been suggested that the muscle aerobic capacity of fishes is sufficient to meet the cost of protein synthesis associated with high growth rate (Blier, Pelletier \& Dutil, 1997). The maintenance of high aerobic enzyme activity can also be seen as a mechanism that allows fish to efficiently metabolise the exogenous and endogenous energy reserves during periods of food restriction and enables fish to rapidly resume growth upon re-feeding (Lamarre et al., in press).

Aspartate aminotransferase activity is indicative of the capacity to oxidise amino acids for energy production or to mobilize amino acids for protein synthesis. At 30 and $60 \mathrm{DPH}$, the higher AST activity observed for spotted wolffish at higher temperatures is either representative of the higher scope for growth, higher protein turnover rate or enhanced energy expenditure at that temperature. Failure to correlate AST activity to SGR supports the latter hypothesis. 
In general, marine larval fish display poor assimilation efficiency for protein (Roennestad, RojasGarcia, Tonheim \& Conceicao, 2001) and do not present any tryptic activity at hatching (Gawlicka et al., 2000; Cahu \& Zambonino-Infante, 2001). Our results, in accordance with other studies on wolffishes, indicate that wolffish present elevated tryptic activity at hatch (Lamarre et al., 2004; in press).

Trypsin activity was higher at lower temperatures (Figure 2d) and correlated well with SGR. High trypsin activity and stronger correlation at lower temperatures can clearly be seen as an advantage. After unfavourable periods, e.g. under temperature conditions which reduce kinetic efficiency of trypsin, such a positive compensation mechanism renders available protein energy from food sources or internal reserves more efficiently harnessed and available for growth (e.g. compensatory growth) and physiological maintenance. Lamarre et al. (in press), working with newly hatched $A$. lupus, observed the same trend but this time in periods of restricted feeding. In their study, heavily restricted-fish experiencing slower growth displayed significantly higher levels of trypsin activity at a given weight compared to well-fed fish. Both studies thus suggest that reduced growth either by restricted diet or low temperature conditions, is counter-balanced with an increased capacity to digest protein. The strong relationship and steepness of the slope obtained at $5^{\circ} \mathrm{C}$, give a clear indication that in order to achieve high growth rates encountered at larval stages, fish rely heavily on trypsin activity. This is in accordance with the conclusions of Blier et al. (1997) that suggest that the utilization of amino acids by the fish (for growth) could be limited by the rate of nutrient production by digestive enzymes or by their transport.

The reverse effect of temperature on trypsin activity is seen on glycolytic enzyme activity ( $P K$ and LDH), i.e. lower activity at lower temperature (negative compensation). Furthermore, LDH activity scales positively with growth rate. Clarke et al. (1992) found that the LDH activity in entire lane snapper (Lutjanus synagris L.) larvae was higher in fish raised at $28{ }^{\circ} \mathrm{C}$ than at $25{ }^{\circ} \mathrm{C}$. Vézina \& Guderley (1991) also saw a negative temperature compensation of LDH activity in three-spined stickleback (Gasterosteus aculeatus L.). Mathers, Houlihan \& Cunningham (1992) and Pelletier, Dutil, Blier \& Guderley (1994) working with Atlantic cod (Gadus morhua L.) also found a positive correlation between LDH activity and SGR.

An interspecific comparison exercise reveals that on hatching day, activity of AST, LDH and PK for newly-hatched $A$. minor (present work) and $A$. lupus (Lamarre et al., 2004) of similar quality and incubated at the same temperature $\left(5-6^{\circ} \mathrm{C}\right)$, are higher in $A$. minor for trypsin, AST, LDH and PK (53.8, 6.6, 36.0\%, respectively). These initial differences in metabolic capacities early in life could be partly responsible for the superior performances of $A$. minor at colder rearing temperatures. This is in line with the findings of Galloway \& Falk-Petersen (2000) who explained faster post-hatch growth of spotted wolffish to more numerous but smaller white muscle fibers compared to the Atlantic wolffish. Hansen \& Falk-Petersen (2002), working on spotted wolffish, achieved comparable growth and survival results within a similar range of temperatures. They indicated that maximal expression of early growth capacity and mortality of spotted wolffish was reached at $12^{\circ} \mathrm{C}$.

Similarities with commercial salmonid species (Salmo, Oncorhynchus and Salvelinus sp.), e.g. big eggs and precocious ontogeny at hatch, suggest that significant improvement of incubation and first-feeding success for spotted wolfish is conceivable given adequate research efforts. Our results and those of Lamarre et al. (2004) clearly illustrate that wolffishes display efficient mechanisms to cope with unfavourable growth conditions during the early stages (i.e. scarcity of food or suboptimal temperatures), and that trypsin deficiency is not the main agent responsible for poor survival during the first-feeding operations, but rather the failure to initiate feeding. Therefore, we suggest that egg quality, incubation protocols and broodstock nutrition be targeted for further investigations to improve survival rates. 


\section{Acknowledgements}

The authors would like to express their gratitude to François Veaux and Bruno Archer for their technical assistance throughout the experiment. The financial support of MAPAQ, FQRNT and the research network AquaNet (project no. AP34) to NLF and PB are gratefully acknowledged. We also wish to thank Dr. Laura Halfyard for her editing of this paper.

\section{References}

Bélanger, F., Blier, P.U. \& Dutil, J.-D. (2002) Digestive capacity and compensatory growth in Atlantic cod (Gadus morhua). Fish Physiology and Biochemistry 26, 121-128.

Blier, P.U., Dutil, J.-D., Lemieux, H., Bélanger, F. \& Bitetera, L. (2007) Phenotypic flexibility of digestive system in Atlantic cod (Gadus morhua). Comparative Biochemistry and Physiology AMolecular \& Integrative Physiology 146, 174-179.

Blier, P.U. \& Guderley, H. (1988) Metabolic responses to cold acclimation in the swimming musculature of lake whitefish, Coregonus clupeaformis. Journal of Experimental Zoology 246, 244252.

Blier, P., Pelletier, D. \& Dutil, J-D. (1997) Does aerobic capacity set a limit on fish growth rate? Reviews in Fisheries Science 5, 323-340.

Bureau, D.P., Kaushik, S.J., \& Young Cho, C. (2002) Bioenergetics. In: Fish Nutrition, (ed. by E. Halver and R.W. Hardy), pp. 1-59. Academic Press Ltd., New York.

Cahu, C. \& Zambonino-Infante, J. (2001) Substitution of live food by formulated diets in marine fish larvae. Aquaculture 200, 161-180.

Cahu, C.L., Zambonino-Infante, J.L., Quazuguel, P. \& Le Gall, M.M. (1999) Protein hydrolysate vs fish meal in compound diets for 10-day old sea bass Dicentrarchus labrax larvae. Aquaculture 171, 109-119.

Carter, C.G., Ye, S.-Y., Houlihan, D.F., McCarthy, I.D. \& Davison, I. (1995) Effect of feeding on the tissue free amino acid concentration in rainbow trout (Oncorhynchus mykiss Walbaum). Fish Physiology and Biochemistry 14, 153-164.

Clarke, M.E., Calvi, C., Domeier, M., Edmonds, M. \& Walsh, P.J. (1992) Effects of nutrition and temperature on metabolic enzyme activities in larval and juvenile red drum, Sciaenops ocellatus, and lane snapper, Lutjanus synagris. Marine Biology 112: 31-36.

Clarke, A. \& Johnston, N.M. (1999) Scaling of metabolic rate with body mass and temperature in teleost fish. Journal of Animal Ecology 68, 893-905.

Desjardins, M., Le François, N.R., Fletcher, G.L. \& Blier, P.U. (2006) Seasonal modulation of plasma antifreeze protein levels in Atlantic (Anarhichas lupus) and spotted wolffish (A. minor). Journal of Experimental Marine Biology and Ecology 335, 142-150. 
Falk-Petersen, I.-B. \& Hansen T.K. (2001) Organ differentiation in newly hatched common wolffish. Journal of Fish Biology 59, 1465-1482.

Falk-Petersen, I.-B. \& Hansen, T. K. (2003) Early ontogeny of the spotted wolffish (Anarhichas minor Olafsen). Aquaculture Research 34 (12), 1059-1067.

Falk-Petersen, I.-B., Hansen, T.K., Fieler, R. \& Sunde, L.M. (1999) Cultivation of the spotted wolffish Anarhichas minor (Olafsen)- a new candidate for cold-water fish farming. Aquaculture Research 30, 711-718.

Foss, A., Imsland, A.K., Falk-Petersen, I.-B. \& Oiestad, V. (2004) A review of the culture potential of spotted wolffish Anarhichas minor Olafsen. Reviews in Fish Biology and Fisheries 14, 277-294.

Galloway, T.F. \& Falk-Petersen, I.-B. (2000) Comparative muscle growth in common and spotted wolffish. Comparative Biochemistry and Physiology Part A 126: S54.

Gawlicka, A., Parent, B., Horn, M.H., Ross, N., Opstad, I. \& Torrissen, O.J. (2000) Activity of digestive enzymes in yolk-sac larvae of Atlantic halibut (Hippoglossus hippoglossus): indication of readiness for first-feeding. Aquaculture 184, 303-314.

Hansen, T. K. and Falk-Petersen, I. B. (2001) The influence of rearing temperature on early development and growth of spotted wolffish Anarhichas minor (Olafsen). Aquaculture Research 32 (5), 369-378.

Hansen, T.K. \& Falk-Petersen, I.-B. (2002) Growth and survival of first-feeding spotted wolffish (Anarhichas minor Olafsen) at various temperature regimes. Aquaculture Research 33, 1119-1127.

Hardewig, I. \& Van Dijk, P.L.M. (2003) Is digestive capacity limiting growth at low temperatures in roach? Journal of Fish Biology 62, 358-374.

Houlihan, D.F., Hall, S.J., Gray, C. \& Noble, B.S. (1988) Growth rates and protein turnover in atlantic cod, Gadus morhua. Canadian Journal of Fisheries and Aquatic Sciences 45, 951-964.

Houlihan, D.F., McCarthy, I.D., Carter, C.G. \& Martin, F. (1995) Protein turnover and amino acid flux in fish larvae. Mass rearing of juvenile Fish, Bergen (Norway), ICES Marine Science Symposia 201, 87-99.

Jobling, M. (1995) Environmental biology of fishes. Fish and Fisheries Series. Chapman and Hall Inc., London, 455 pp.

Jobling, M. (2001) Nutrient portioning and the influence of feed composition on body composition. In: Food intake in Fish. (ed. by D. Houlihan, T. Boujard \& M. Jobling), pp. 354-375. Blackwell Science, Oxford.

Johnston, I.A. \& Dunn, J. (1987) Temperature acclimation and metabolism in ectotherms with particular reference to teleost fish. Symposium of the Society for Experimental Biology 41, 67-93.

Lamarre, S.G., Le Francois, N.R., Falk-Petersen, I.-B. \& Blier, P.U. (2004) Can digestive and metabolic enzyme activity levels predict growth rate and survival of newly hatched Atlantic wolffish (Anarhichas lupus)? Aquaculture Research 35, 608-613.

Lamarre, S.G., Le François, N.R., Lemieux, H., Falk-Petersen I.-B. \& Blier, P.U. (in press). The digestive and metabolic enzyme activity profiles of a non-metamorphic marine fish species: effects of feed type and feeding level. Canadian Journal of Fisheries and Aquatic Sciences. 
Le François N.R., Lemieux H. \& Blier P.U. (2002) Biological and technical evaluation of the potential of marine and anadromous fish species for cold-water mariculture. Aquaculture Research 33, 95108.

Lemieux, H., Blier, P.U. \& Dutil, J.-D. (1999) Do digestive enzymes set a physiological limit on growth rate and food conversion efficiency in the Atlantic cod (Gadus morhua)? Fish Physiology and Biochemistry 20, 293-303.

Lemieux, H., Le François, N.R. \& Blier, P.U. (2003) The early ontogeny of digestive and metabolic enzyme activities in two commercial strains of Arctic charr (Salvelinus alpinus L.). Journal of Experimental Zoology 299A, 151-160.

Mathers, E.M., Houlihan, D.F. \& Cunningham, M.J. (1992) Nucleic acid concentrations and enzyme activities as correlates of growth rate of the saithe (Pollachius virens): growth rates estimates of open-sea fish. Marine Biology 112, 363-369.

Pelletier, D., Dutil, J.-D., Blier, P. \& Guderley, H. (1994) Relation between growth rate and metabolic organization of white muscle, liver and digestive tract in cod, Gadus morhua. Journal of Comparative Physiology B 164, 173-190.

Pelletier, D., Guderley, H. \& Dutil, J.-D. (1993) Does aerobic capacity of fish muscle change with growth rates? Fish Physiology and Biochemistry 12, 83-93.

Pérez-Jiménez, A., Guedes, M.J., Morales, A.E. \& Oliva-Teles, A. (In press) Metabolic responses to short starvation and refeeding in Dicentrarchus labrax. Effect of dietary composition. Aquaculture.

Preiser, H., Schmitz, J., Maestracci, R.K. \& Crane, R.K. (1975) Modification of an assay for trypsin and its application for the estimation of enteropeptidase. Clinica Chimica Acta 59, 169-175.

Roennestad, I., Rojas-Garcia, C.R., Tonheim, S.K. \& Conceicao, L.E.C. (2001) In vivo studies of digestion and nutrient assimilation in marine fish larvae. Aquaculture 201, 161-175.

Sala, R., Santamaria, C.A. \& Crespo, S. (2005) Growth of organ systems of Dentex dentex (L.) and Psetta maxima (L.) during larval development. Journal of Fish Biology 66, 315-326.

Savoie, A., Le François, N.R., Cahu, C., Blier, P.U. \& Andreassen, I. (2006) Do protein hydrolysate improve survival and growth of newly-hatched spotted wolffish (Anarhichas minor), a nonmetamorphic aquaculture fish species. Aquaculture 261, 782-788.

Smith, P.K., Krohn, R.I., Hermanson, G.T., Mallia, A.K., Gartner, F.H., Provenzano, M.D., Fujimoto, E.K., Goeke, N.M., Olson, B.J. \& Klenk, D.C. (1985) Measurement of protein using bicinchoninic acid. Analytical Biochemistry 150, 76-85.

Somero, G.N. (1969) Enzymic mechanisms of temperature compensation: immediate and evolutionary effects of temperature in enzymes of aquatic poikilotherms. American Naturalist 933, 517-530.

Vézina, G.B. \& Guderley, H. (1991) Anatomic and enzymatic responses of the three-spined stickleback, Gastrosteus aculeatus to thermal acclimation and acclimatization. Journal of Experimental Zoology 258, 277-287.

Zar, J.H., 1984. Biostatistical analysis. Prentice Hall, Englewood Cliffs, New Jersey, 718 pp. 

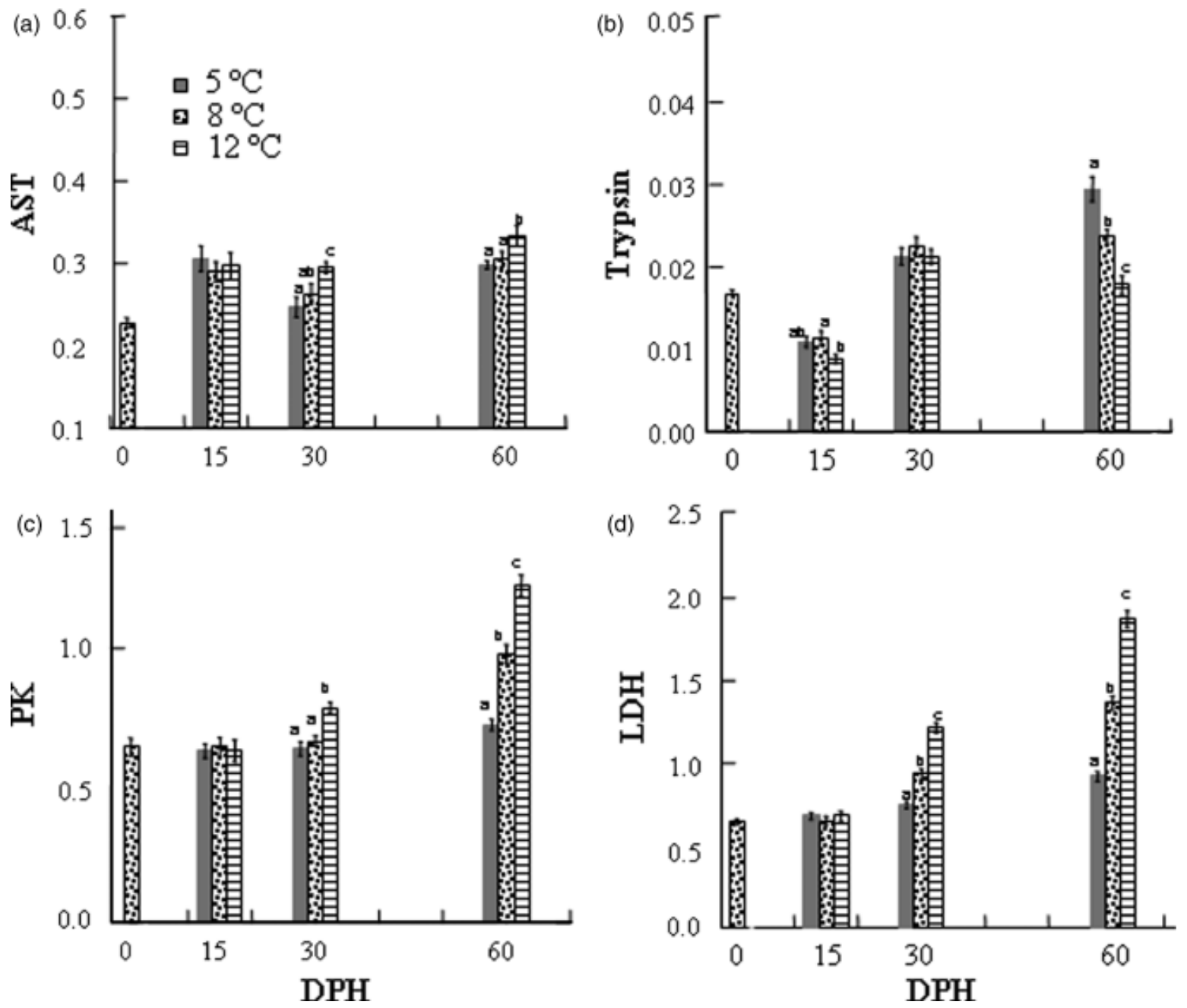

Figure 1. Enzymatic activities expressed as U.mg protein ${ }^{-1}$ of a) AST, b) trypsin, c) PK and d) LDH of spotted wolffish (A. minor) from 0-60 days post-hatching, at different temperatures. 

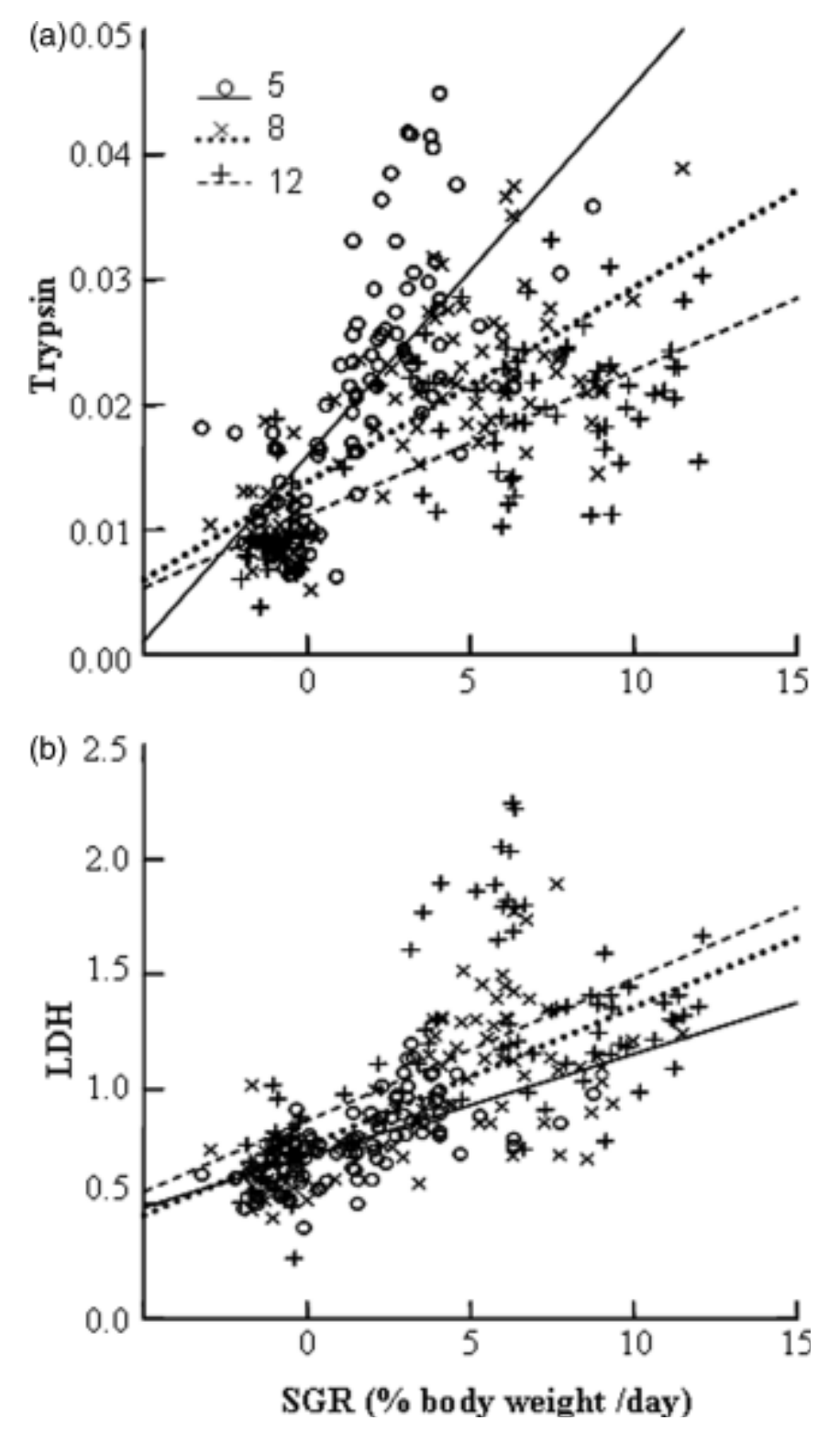

Figure 2. Linear regression of a) trypsin and b) LDH expressed as $U \cdot \mathrm{mg}$ protein $^{-1}$ of newly-hatched spotted wolffish (A. minor) as a function of SGR for different temperatures. 
Table 1. Parameters used for the enzyme analysis (Lemieux et al., 2003; Prieser et al., 1975; with modifications).

\begin{tabular}{cccc}
\hline Enzyme & Substrate & Buffer solution & $\mathrm{pH}$ \\
\hline AST & Aspartate aminotransferase $(22 \mathrm{mM})$ & Phosphate $(100 \mathrm{mM})$ & 7.4 \\
CS & Oxaloacetate $(0.2 \mathrm{mM})$ & Imidazole- $\mathrm{HCl}(100 \mathrm{mM})$ & 8.0 \\
Trypsin & Benzoyl-L-arginine-p-nitroanilide & Tris- $\mathrm{HCl} 0.2 \mathrm{M}, \mathrm{CaCl}$ 0.04M & 8.0 \\
PK & Phospho(enol)pyruvate $(5 \mathrm{mM})$ & Imidazole- $\mathrm{HCl}(100 \mathrm{mM})$ & 7.5 \\
LDH & Pyruvate $(1 \mathrm{mM})$ & Imidazole- $\mathrm{HCl}(50 \mathrm{mM})$ & 7.0 \\
\hline
\end{tabular}

